\title{
Respiratory symptoms and home environment in children: a national survey
}

\author{
M L Burr, H R Anderson, J B Austin, L S Harkins, B Kaur, D P Strachan, J O Warner
}

\begin{abstract}
Background-Respiratory diseases are common in childhood and may lead to chronic disease in adult life; environmental factors probably play an important part in their causation.

Methods-A survey of respiratory symptoms in children aged 12-14 years was conducted throughout Great Britain as part of the International Study of Asthma and Allergies in Childhood (ISAAC). Information was obtained on certain aspects of the home environment in order to assess their importance as risk factors.

Results-The response rate was $79.3 \%$, and 25393 children in 93 schools participated. In a multiple regression analysis, wheeze was reported more often in nonmetropolitan areas and in association with active smoking, passive smoking, the presence of a furry pet, bottled gas, paraffin, and other unusual heating fuels; small regional differences persisted. Current smoking, previous smoking, and passive smoking accounted for $10.4 \%, 6.8 \%$, and $6.5 \%$, respectively, of wheezing in the past 12 months, and furry pets accounted for $5.0 \%$. Cough and phlegm were associated with active and passive smoking and with the miscellaneous fuels; similar associations were found for rhinitis, but were less consistent for rhinitis occurring in spring and summer. Gas cooking showed little association with respiratory symptoms.

Conclusions-Passive as well as active smoking is an important cause of respiratory symptoms in adolescence. Pets seem to increase the risk of wheeze and rhinitis, and fumes from certain unusual heating fuels may have adverse effects. Home environment and geographical location have independent effects on the prevalence of respiratory symptoms. (Thorax 1999;54:27-32)
\end{abstract}

Keywords: asthma; wheeze; cough; rhinitis; housing; smoking

Child Health,

Southampton General

Hospital,

Southampton

SO16 6YD, UK

JO Warner

Correspondence to: Dr M L Burr.

Received 8 January 1998 Returned to author 25 February 1998

Revised version received

27 August 1998

Accepted for publication

3 September 1998 chronic disease. ${ }^{12}$ In a survey published in 1970 the prevalence of chronic cough among children in different areas ran parallel with the inception rates of incapacity due to bronchitis
Respiratory disease is a major cause of ill health and school absence in children. Surveys in different parts of Britain have shown a these symptoms are mostly caused by quite minor illness, they are liable to persist into in men and the death rates from bronchitis and pneumonia in middle aged men and women, suggesting common aetiological factors. ${ }^{3}$ It is therefore important to study respiratory symptoms in childhood and to discover what environmental factors are involved, particularly those that are potentially modifiable. Cigarette smoking (active and passive) are obvious factors to be considered; gas cooking ${ }^{4}$ and pet ownership $^{5}$ have also been implicated, although the evidence is less consistent.

Many surveys have shown associations between respiratory symptoms and the home environment, but they have usually been conducted in localised areas. This survey examines the relationship between a range of respiratory symptoms and housing factors throughout Great Britain. The International Study of Asthma and Allergies in Childhood (ISAAC) is a survey that is being conducted in numerous countries, using a common protocol and a validated questionnaire. ${ }^{6}$ When this questionnaire was administered in Britain the opportunity was taken to incorporate some questions about the home environment. The objective was, firstly, to examine the importance of these environmental factors nationally in relation to respiratory symptoms in children and, secondly, to see whether they explained any geographical differences that concurrently emerged from the survey.

\section{Methods}

Details have already been published about the ISAAC survey ${ }^{6}$ and the way it was conducted in Britain. ${ }^{7}$ One mixed comprehensive school was randomly selected from each local education authority in England, Wales, and Scotland. The questionnaire was completed in class, without conferring, by the children in two school years, aged 12-14 years; in addition to the "core" ISAAC questions on asthma and rhinitis, it included other questions about wheeze, cough, phlegm, pet ownership, cooking and heating fuels, house ownership, and cigarette smoking by the child and other residents of the child's house. Questions about symptoms all related to the previous 12 months. One question asked whether wheezing had ever been severe enough to limit speech to one or two words between breaths ("speech limiting wheeze"). Rhinitis was defined as a positive answer to a question about "a problem with sneezing, or a runny or blocked nose, when you DID NOT have a cold or the flu"; results presented here relate to rhinitis "accompanied by itchy watery eyes" and spring/ summer rhinitis, defined as rhinitis with itchy watery eyes that occurred only in the months 
Table 1 Prevalence of symptoms in boys and girls

\begin{tabular}{|c|c|c|c|c|}
\hline \multirow[b]{2}{*}{ Symptom } & \multicolumn{2}{|c|}{ Prevalence (\%) } & \multirow{2}{*}{$\begin{array}{l}\text { Adjusted odds ratio } \\
\text { (boys }=1.00)\end{array}$} & \multirow{2}{*}{$\begin{array}{l}95 \% \text { Confidence } \\
\text { intervals }\end{array}$} \\
\hline & Boys & Girls & & \\
\hline Wheeze in past year & 32.4 & 35.3 & $1.11^{\star \star \star}$ & (1.06 to 1.18 ) \\
\hline Speech limiting wheeze & 8.2 & 9.5 & $1.15^{\star \star}$ & (1.05 to 1.26$)$ \\
\hline Wheeze without colds & 20.8 & 22.0 & 1.05 & $(0.98$ to 1.12$)$ \\
\hline Rhinitis, itchy eyes & 15.8 & 20.8 & $1.39^{\star \star \star}$ & (1.31 to 1.49$)$ \\
\hline Spring/summer rhinitis & 5.2 & 7.3 & $1.40^{\star \star \star}$ & (1.26 to 1.55$)$ \\
\hline Cough without colds & 28.5 & 30.3 & $1.08^{\star \star \star}$ & (1.02 to 1.14$)$ \\
\hline Phlegm with colds & 56.9 & 65.5 & $1.42^{\star \star \star}$ & ( 1.35 to 1.50$)$ \\
\hline Phlegm without colds & 21.7 & 20.8 & $0.91^{\star \star}$ & (0.86 to 0.97$)$ \\
\hline$>3$ colds in last year & 23.1 & 31.5 & $1.51^{\star \star \star}$ & (1.43 to 1.60$)$ \\
\hline Dry night cough without colds & 43.4 & 47.4 & $1.14^{\star \star \star}$ & (1.09 to 1.20$)$ \\
\hline
\end{tabular}

${ }^{\star} \mathrm{p}<0.05,{ }^{\star \star} \mathrm{p}<0.01,^{\star \star \star} \mathrm{p}<0.001$

Odds ratios are adjusted for age, region, and all the environmental factors in subsequent tables.

from March to September (inclusive). The survey was conducted in the 1995 spring term in all areas. Information about passive smoking related to "anyone you live with" who smokes cigarettes regularly at home. Children were then asked, "Have you ever smoked a cigarette?" "If YES, how often do you smoke nowadays?"

The data were analysed using logistic regression in GLIM. ${ }^{8}$ All variables of interest were included in the model. This analysis was restricted to the children who answered all the exposure questions. The population attributable risk was calculated using the formula $\mathrm{p}(\mathrm{r}-1) /\{\mathrm{p}(\mathrm{r}-1)+1\}$, where $\mathrm{p}$ is the prevalence of the exposure and $r$ is the relative risk due to the exposure, approximated by the odds ratio. ${ }^{9}$

\section{Results}

The survey involved 93 schools containing 32033 eligible children, of whom 27507 participated in the survey. The response did not vary significantly between England, Wales and Scotland or between metropolitan and nonmetropolitan areas. ${ }^{7}$ A total of 25393 children (79.3\% of those originally available) answered all the questions on home environment and are the subject of this report.

Table 1 shows the prevalence of various symptoms in boys and girls with odds ratios adjusted for age and the environmental factors under consideration. All these symptoms were more frequently reported by girls than boys, except phlegm without colds. A rising prevalence with age occurred for wheeze in the last 12 months, wheeze without colds, rhinitis (both types), phlegm with colds, and more than three colds in the last year, while the prevalence declined with age for cough without colds, phlegm without colds, and dry night cough without colds.

Data from this survey showing the prevalence of wheeze and cough in the various regions of Britain have already been published ${ }^{7}$; similar data on the regional prevalence of rhinoconjunctivitis are in preparation. Although the differences were not great, Scotland had the highest prevalence of wheeze and of rhinitis with itchy eyes, and the lowest prevalence of cough without a cold. When adjustments were made for age, sex, and the environmental factors under consideration here, all the symptoms except speech limiting wheeze and spring/summer rhinitis still showed significant

Table 2 Prevalence of symptoms in children grouped by environmental factors

\begin{tabular}{|c|c|c|c|c|c|c|c|c|c|c|c|}
\hline \multirow[b]{2}{*}{ Environmental factor } & \multirow[b]{2}{*}{ Total no. } & \multicolumn{10}{|c|}{ Percentage prevalence of symptoms in children in each environmental group } \\
\hline & & Wheeze & $\begin{array}{l}\text { Speech limiting } \\
\text { wheeze }\end{array}$ & $\begin{array}{l}\text { Wheeze } \\
\text { without } \\
\text { colds }\end{array}$ & $\begin{array}{l}\text { Rhinitis, } \\
\text { itchy eyes }\end{array}$ & $\begin{array}{l}\text { Spring/summer } \\
\text { rhinitis }\end{array}$ & $\begin{array}{l}\text { Cough } \\
\text { without } \\
\text { colds }\end{array}$ & $\begin{array}{l}\text { Phlegm } \\
\text { with colds }\end{array}$ & $\begin{array}{l}\text { Phlegm } \\
\text { without colds }\end{array}$ & $\begin{array}{l}>3 \text { colds } \\
\text { per year }\end{array}$ & $\begin{array}{l}\text { Dry night } \\
\text { cough without } \\
\text { colds }\end{array}$ \\
\hline \multicolumn{12}{|l|}{ Area } \\
\hline Metropolitan & 8955 & 30.8 & 8.0 & 19.4 & 18.9 & 6.0 & 32.3 & 60.2 & 23.2 & 27.2 & 48.4 \\
\hline Non-metropolitan & 16438 & 35.5 & 9.3 & 22.5 & 18.5 & 6.7 & 27.8 & 61.7 & 20.2 & 27.4 & 43.8 \\
\hline \multicolumn{12}{|l|}{ Pets } \\
\hline None & 7204 & 31.6 & 8.0 & 19.6 & 17.4 & 5.7 & 29.6 & 58.0 & 20.8 & 25.6 & 44.6 \\
\hline Furry pets & 16728 & 34.8 & 9.2 & 22.2 & 19.1 & 6.7 & 29.2 & 62.6 & 21.4 & 28.3 & 45.6 \\
\hline Other pets only & 1461 & 34.5 & 8.5 & 21.5 & 20.1 & 7.5 & 31.0 & 61.1 & 21.1 & 24.5 & 46.3 \\
\hline \multicolumn{12}{|l|}{ Cooking fuel } \\
\hline Electricity only & 9277 & 33.9 & 8.9 & 21.6 & 18.0 & 6.8 & 28.2 & 60.6 & 20.4 & 27.2 & 43.7 \\
\hline Gas & 15492 & 33.8 & 8.8 & 21.1 & 19.0 & 6.3 & 30.3 & 61.4 & 21.8 & 27.4 & 46.5 \\
\hline Other only & 624 & 35.7 & 9.4 & 25.3 & 19.5 & 6.2 & 25.0 & 66.1 & 18.4 & 26.8 & 43.0 \\
\hline \multicolumn{12}{|l|}{ Heating fuel } \\
\hline Electricity only & 6795 & 32.0 & 8.1 & 20.0 & 17.1 & 5.6 & 30.0 & 57.1 & 20.9 & 26.5 & 45.6 \\
\hline Mains gas & 12294 & 33.6 & 8.6 & 21.3 & 19.0 & 6.9 & 29.5 & 61.8 & 21.1 & 26.9 & 45.4 \\
\hline Coal, wood, oil & 4109 & 34.8 & 9.3 & 21.7 & 17.4 & 6.5 & 26.3 & 64.6 & 20.0 & 27.3 & 42.5 \\
\hline Bottled gas, paraffin & 1526 & 38.0 & 11.6 & 25.4 & 23.8 & 6.5 & 32.3 & 64.1 & 24.8 & 31.6 & 49.5 \\
\hline Other & 669 & 42.1 & 12.4 & 26.8 & 25.1 & 7.0 & 33.2 & 63.5 & 26.9 & 34.5 & 51.2 \\
\hline \multicolumn{12}{|l|}{ Housing } \\
\hline Owned & 5059 & 34.4 & 10.0 & 22.1 & 20.6 & 5.8 & 36.2 & 58.3 & 26.3 & 30.1 & 50.6 \\
\hline Council & 1013 & 34.9 & 9.7 & 21.5 & 21.4 & 7.4 & 32.7 & 63.2 & 23.2 & 27.9 & 47.0 \\
\hline Other rented & 18338 & 33.5 & 8.3 & 21.2 & 17.9 & 6.7 & 27.2 & 62.0 & 19.7 & 26.3 & 43.7 \\
\hline Other & 983 & 36.5 & 11.0 & 22.5 & 20.3 & 5.9 & 32.8 & 58.9 & 22.2 & 30.5 & 48.8 \\
\hline \multicolumn{12}{|l|}{ Passive smoking } \\
\hline Nobody & 13498 & 31.8 & 7.6 & 20.0 & 17.2 & 7.0 & 25.5 & 60.6 & 17.7 & 25.3 & 41.2 \\
\hline Mother only & 2963 & 34.5 & 9.1 & 21.6 & 19.6 & 6.4 & 32.2 & 62.1 & 23.4 & 28.1 & 48.8 \\
\hline Father only & 3224 & 34.3 & 9.6 & 21.5 & 17.7 & 6.7 & 31.4 & 59.6 & 22.8 & 28.1 & 46.2 \\
\hline Both & 2908 & 34.9 & 9.2 & 22.6 & 20.1 & 5.7 & 32.7 & 62.4 & 25.6 & 28.3 & 50.1 \\
\hline Other & 2800 & 41.5 & 13.5 & 26.9 & 24.5 & 4.8 & 39.3 & 63.6 & 29.9 & 34.2 & 56.0 \\
\hline \multicolumn{12}{|l|}{ Active smoking } \\
\hline Never & 15672 & 30.2 & 7.5 & 18.8 & 16.7 & 6.1 & 27.2 & 56.8 & 17.4 & 24.9 & 40.6 \\
\hline Ex-smoker & 6433 & 36.6 & 9.9 & 23.0 & 20.5 & 6.7 & 29.6 & 66.3 & 24.0 & 28.7 & 49.9 \\
\hline$<$ Once weekly & 699 & 43.7 & 12.1 & 27.7 & 23.2 & 9.4 & 28.8 & 70.9 & 25.0 & 33.9 & 53.5 \\
\hline Weekly not daily & 725 & 43.3 & 11.5 & 27.8 & 22.4 & 5.9 & 34.4 & 72.8 & 30.5 & 35.1 & 56.3 \\
\hline Daily & 1864 & 48.1 & 14.2 & 32.6 & 26.1 & 7.9 & 45.5 & 72.9 & 38.6 & 37.0 & 62.3 \\
\hline (Missing answers) & - & $(1.7)$ & $(1.7)$ & $(1.7)$ & $(1.4)$ & $(1.5)$ & $(1.2)$ & $(1.0)$ & $(1.4)$ & $(0.4)$ & $(0.8)$ \\
\hline
\end{tabular}


Table 3 Results of logistic regression for wheeze and rhinitis in past 12 months in relation to environmental factors

\begin{tabular}{|c|c|c|c|c|c|}
\hline \multirow[b]{2}{*}{ Environmental factor } & \multicolumn{5}{|c|}{ Odds ratios (95\% CI) for symptoms, adjusted for age, sex, region, and other factors shown } \\
\hline & Wheeze & Speech limiting wheeze & Wheeze without colds & Rhinitis, itchy eyes & Spring/summer rhinitis \\
\hline Area $($ Metropolitan $=1.00)$ & $\star \star \star$ & $\star$ & $\star \star \star$ & & \\
\hline Non-metropolitan & $1.20(1.12$ to 1.28$)$ & $1.14(1.02$ to 1.28$)$ & $1.15(1.06$ to 1.25$)$ & $0.94(0.86$ to 1.02$)$ & $1.09(0.95$ to 1.24$)$ \\
\hline Pets $($ None $=1.00)$ & & & & & \\
\hline Furry pets & $1.08(1.01$ to 1.14$)$ & $1.09(0.98$ to 1.21$)$ & $1.10(1.02$ to 1.18$)$ & $1.08(1.00$ to 1.16$)$ & $1.16(1.02$ to 1.30$)$ \\
\hline Other pets only & $1.13(1.00$ to 1.28$)$ & $1.05(0.86$ to 1.29$)$ & $1.11(0.96$ to 1.28$)$ & $1.20(1.04$ to 1.39$)$ & $1.34(1.07$ to 1.67$)$ \\
\hline \multicolumn{6}{|c|}{ Cooking fuel $($ Electricity only $=1.00)$} \\
\hline Gas & $1.03(0.97$ to 1.10$)$ & $1.02(0.93$ to 1.13$)$ & $0.99(0.93$ to 1.06$)$ & $1.05(0.98$ to 113$)$ & $0.90(0.81$ to 1.01$)$ \\
\hline Other only & $0.99(0.83$ to 1.18$)$ & $0.95(0.71$ to 1.27$)$ & $1.17(0.96$ to 1.42$)$ & $1.11(0.89$ to 1.38$)$ & $0.87(0.61$ to 1.23$)$ \\
\hline Heating fuel (Electricity only $=1.00)$ & 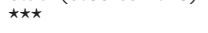 & $\star \star$ & 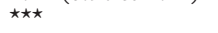 & 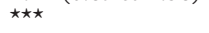 & 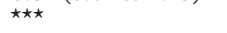 \\
\hline Mains gas & $1.10(1.03$ to 1.17$)$ & $1.10(0.99$ to 1.23$)$ & $1.11(1.03$ to 1.19$)$ & $1.18(1.09$ to 1.28$)$ & $1.33(1.17$ to 1.51$)$ \\
\hline Coal, wood, oil & $1.07(0.98$ to 1.16$)$ & $1.13(0.98$ to 1.32$)$ & $1.01(0.91$ to 1.12$)$ & $1.05(0.94$ to 1.17$)$ & $1.12(0.94$ to 1.33$)$ \\
\hline Bottled gas, paraffin & $1.21(1.08$ to 1.37$)$ & $1.38(1.55$ to 1.66$)$ & $1.27(1.11$ to 1.45$)$ & $1.47(1.28$ to 1.68$)$ & $1.21(0.96$ to 1.52$)$ \\
\hline Other & $1.46(1.23$ to 1.72$)$ & $1.52(1.18$ to 1.96$)$ & $1.36(1.13$ to 1.64$)$ & $1.62(1.33$ to 1.96$)$ & $1.34(0.97$ to 1.85$)$ \\
\hline \multicolumn{6}{|l|}{ Housing (Owned $=1.00)$} \\
\hline Council & $0.96(0.90$ to 1.03$)$ & $1.10(0.98$ to 1.23$)$ & $0.99(0.83$ to 1.17$)$ & $1.08(0.99$ to 1.17$)$ & $0.91(0.80$ to 1.05$)$ \\
\hline Other rented & $1.02(0.89$ to 1.16$)$ & $1.10(0.88$ to 1.36$)$ & $1.02(0.94$ to 1.11$)$ & $1.19(1.02$ to 1.39$)$ & $1.18(0.92$ to 1.51$)$ \\
\hline Other & $1.08(0.94$ to 1.24$)$ & $1.25(1.01$ to 1.54$)$ & $1.03(0.87$ to 1.22$)$ & $1.12(0.96$ to 1.32$)$ & $0.93(0.71$ to 1.23$)$ \\
\hline Passive smoking $($ Nobody $=1.00)$ & $\star \star \star$ & $\star \star \star$ & 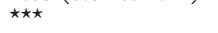 & 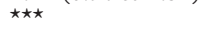 & 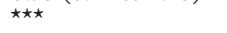 \\
\hline Mother only & $1.08(0.99$ to 1.18$)$ & $1.13(0.98$ to 1.31$)$ & $1.06(0.96$ to 1.17$)$ & $1.09(0.98$ to 1.21$)$ & $0.90(0.76$ to 1.06$)$ \\
\hline Father only & $1.10(1.01$ to 1.20$)$ & $1.23(1.08$ to 1.42$)$ & $1.08(0.98$ to 1.19$)$ & $0.99(0.89$ to 1.10$)$ & $0.96(0.82$ to 1.12$)$ \\
\hline Both & $1.09(1.00$ to 1.19$)$ & $1.13(0.97$ to 1.31$)$ & $1.11(1.00$ to 1.23$)$ & $1.11(0.99$ to 1.23$)$ & $0.79(0.66$ to 0.94$)$ \\
\hline Other & $1.30(1.19$ to 1.42$)$ & $1.58(1.38$ to 1.81$)$ & $1.26(1.14$ to 1.39$)$ & $1.34(1.21$ to 1.49$)$ & $0.63(0.52$ to 0.77$)$ \\
\hline Active smoking $($ Never $=1.00)$ & 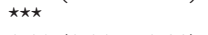 & 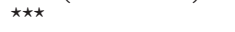 & 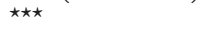 & 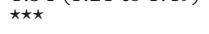 & 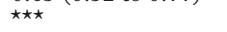 \\
\hline Ex-smoker & $1.29(1.21$ to 1.38$)$ & $1.29(1.17$ to 1.43$)$ & $1.25(1.17$ to 1.35$)$ & $1.23(1.14$ to 1.33$)$ & $1.10(0.98$ to 1.24$)$ \\
\hline$<$ Once weekly & $1.68(1.44$ to 1.97$)$ & $1.58(1.24$ to 2.01$)$ & $1.56(1.31$ to 1.85$)$ & $1.40(1.17$ to 1.69$)$ & $1.52(1.16$ to 1.98$)$ \\
\hline Weekly not daily & $1.65(1.41$ to 1.92$)$ & $1.45(1.14$ to 1.84$)$ & $1.55(1.30$ to 1.84$)$ & $1.33(1.11$ to 1.60$)$ & $0.98(0.71$ to 1.35$)$ \\
\hline Daily & $1.95(1.76$ to 2.16$)$ & $1.74(1.49$ to 2.03$)$ & $1.92(1.72$ to 2.15$)$ & $1.55(1.37$ to 1.74$)$ & $1.42(1.17$ to 1.72$)$ \\
\hline
\end{tabular}

${ }^{\star} \mathrm{p}<0.05,{ }^{\star \star} \mathrm{p}<0.01,{ }^{\star \star \star} \mathrm{p}<0.001$ for heterogeneity.

regional heterogeneity, although it was somewhat reduced for some symptoms. For wheeze, the odds ratio for the area with the highest prevalence (Scotland) versus that with the lowest prevalence (West Midlands) was 1.36 unadjusted and 1.22 adjusted; the corresponding odds ratios for rhinitis with itchy eyes (Scotland versus Trent) were 1.32 and 1.30 , and for cough without a cold (West Midlands versus Scotland) were 1.45 and 1.47 , respectively.

Table 2 shows the prevalence of each symptom in children grouped according to the various environmental factors. The categories in each section are exclusive, and the children are allocated to the lowest applicable category unless indicated otherwise-for example, a house heated by mains gas and coal is classified as being heated by coal. The percentages were calculated after excluding children who did not answer the question about a given symptom (less than $2 \%$ for any symptom). The prevalence of symptoms was highest among those who smoked daily; it was also raised among children exposed to passive smoking, particularly where this involved someone other than (or in addition to) a parent. Prevalence tended to be higher in association with heating fuels other than electricity, particularly bottled gas and paraffin, and even more with the category designated as "other" fuels. This group of fuels was used to a much greater extent in the Scottish islands than elsewhere, being reported by $26.9 \%$ of children in the Western Isles, $10.3 \%$ in Shetland, 7.7\% in Orkney, and less than 5\% in all other areas.

Table 3 shows the odds ratios for wheeze and rhinitis in relation to various environmental factors. In each case the odds ratio is adjusted for all the other environmental factors and for age, sex, and the region. Each form of wheeze was more common in the non-metropolitan than in the metropolitan areas, and significantly associated with active smoking, past or present. It was also associated with passive smoking from someone other than a parent. Possession of a furry pet was associated with any wheeze in the past year and wheeze without colds; it was unrelated to wheeze that occurred only with colds (data not shown; odds ratio 1.01). There were no obvious relationships with cooking fuel, but the associations with bottled gas, paraffin, and other unusual heating fuels were still evident.

For wheeze in the past 12 months the percentage of cases attributable to various factors was calculated (population attributable risk). Among factors that are potentially modifiable, furry pets accounted for $5.0 \%$ of cases (95\% CI 0.7 to 8.6), ex-smoking for $6.8 \%$ (95\% CI 5.1 to 8.7 ), smoking less than weekly for $1.9 \%$ (95\% CI 1.2 to 2.6 ), smoking weekly also for $1.9 \%$ (95\% CI 1.2 to 2.6$)$, smoking daily for $6.7 \%$ (95\% CI 5.4 to 8.0 ), and passive smoking from someone other than (or in addition to) a parent for 3.3\% (95\% CI 2.1 to 4.6); all current active and passive smoking accounted for $10.4 \%$ and $6.5 \%$ of cases, respectively.

Rhinitis with itchy eyes was associated with furry and other pets, several heating fuels, active smoking, and passive smoking by someone other than (or in addition to) a parent; the relationship with "other fuels" was particularly strong. When the condition occurred only in spring or summer it was associated with pets, mains gas heating, and active smoking, but inversely related to passive smoking, particularly by someone other than a parent. Table 4 shows a similar analysis for cough and phlegm. Active smoking was strongly associated with all symptoms, and passive smoking was associated with cough and phlegm that occurred in the absence of a cold. The symptoms tended to occur particularly in houses heated by the miscellaneous fuels, bottled gas, and paraffin. Gas cooking was significantly associated only with 
Table 4 Results of logistic regression for cough and phlegm in relation to environmental factors

\begin{tabular}{|c|c|c|c|c|c|}
\hline \multirow[b]{2}{*}{ Environmental factor } & \multicolumn{5}{|c|}{ Odds ratios ( $95 \%$ CI) for symptoms, adjusted for age, sex, region, and other factors shown } \\
\hline & Cough without colds & Phlegm with colds & Phlegm without colds & $>3$ colds per year & $\begin{array}{l}\text { Dry night cough without } \\
\text { colds }\end{array}$ \\
\hline Area $($ Metropolitan $=1.00)$ & $\star \star$ & & $\star \star \star$ & & $\star \star \star$ \\
\hline Non-metropolitan & $0.90(0.83$ to 0.96$)$ & $0.95(0.89$ to 1.02$)$ & $0.84(0.78$ to 0.91$)$ & $1.03(0.95$ to 1.10$)$ & $0.89(0.83$ to 0.95$)$ \\
\hline Pets $($ None $=1.00)$ & & $\star \star \star \star$ & & $\star \star$ & \\
\hline Furry pets & $0.97(0.91$ to 1.03$)$ & $1.13(1.07$ to 1.20$)$ & $1.01(0.94$ to 1.08$)$ & $1.09(1.02$ to 1.16$)$ & $1.01(0.96$ to 1.07$)$ \\
\hline Other pets only & $1.07(0.94$ to 1.21$)$ & $1.15(1.02$ to 1.29$)$ & $1.02(0.89$ to 1.18$)$ & $0.94(0.82$ to 1.07$)$ & $1.08(0.96$ to 1.21$)$ \\
\hline \multicolumn{6}{|c|}{ Cooking fuel $($ Electricity only $=1.00)$} \\
\hline Gas & $1.04(0.98$ to 1.11$)$ & $1.04(0.99$ to 1.10$)$ & $1.07(1.00$ to 1.14$)$ & $1.02(0.96$ to 1.09$)$ & $1.07(1.01$ to 1.13$)$ \\
\hline Other only & $0.94(0.78$ to 1.15$)$ & $1.12(0.94$ to 1.35$)$ & $0.92(0.74$ to 1.14$)$ & $0.94(0.78$ to 1.14$)$ & $1.05(0.88$ to 1.25$)$ \\
\hline Heating fuel (Electricity only $=1.00)$ & $\star$ & $\star \star \star$ & $\star \star$ & $\star \star \star \star$ & $\star \star$ \\
\hline Mains gas & $0.98(0.92$ to 1.05$)$ & $1.26(1.18$ to 1.34$)$ & $1.01(0.94$ to 1.09$)$ & $1.07(1.00$ to 1.15$)$ & $1.01(0.95$ to 1.08$)$ \\
\hline Coal, wood, oil & $0.93(0.85$ to 1.02$)$ & $1.35(1.24$ to 1.47$)$ & $1.02(0.92$ to 1.13$)$ & $1.08(0.98$ to 1.18$)$ & $0.97(0.89$ to 1.06$)$ \\
\hline Bottled gas, paraffin & $1.08(0.95$ to 1.22$)$ & $1.33(1.18$ to 1.49$)$ & $1.17(1.02$ to 1.33$)$ & $1.27(1.12$ to 1.43$)$ & $1.14(1.01$ to 1.28$)$ \\
\hline Other & $1.23(1.03$ to 1.46$)$ & $1.31(1.11$ to 1.56$)$ & $1.40(1.16$ to 1.69$)$ & $1.50(1.26$ to 1.78$)$ & $1.29(1.10$ to 1.52$)$ \\
\hline Housing $($ Owned $=1.00)$ & $\star \star \star \star$ & $\star \star \star$ & $\star \star \star$ & $\star \star$ & $\star \star \star \star$ \\
\hline Council & $1.33(1.24$ to 1.43$)$ & $0.82(0.76$ to 0.87$)$ & $1.23(1.14$ to 1.33$)$ & $1.11(1.03$ to 1.19$)$ & $1.14(1.07$ to 1.22$)$ \\
\hline Other rented & $1.18(1.02$ to 1.35$)$ & $1.02(0.89$ to 1.16$)$ & $1.11(0.95$ to 1.30$)$ & $1.03(0.89$ to 1.19$)$ & $1.04(0.91$ to 1.18$)$ \\
\hline Other & $1.25(1.08$ to 1.44$)$ & $0.87(0.76$ to 0.99$)$ & $1.07(0.91$ to 1.26$)$ & $1.19(1.03$ to 1.37$)$ & $1.18(1.03$ to 1.34$)$ \\
\hline Passive smoking $($ Nobody $=1.00)$ & 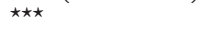 & & $\star \star \star$ & 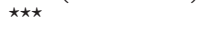 & 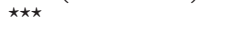 \\
\hline Mother only & $1.23(1.13$ to 1.35$)$ & $1.04(0.96$ to 1.14$)$ & $1.24(1.12$ to 1.37$)$ & $1.08(0.99$ to 1.19$)$ & $1.23(1.13$ to 1.34$)$ \\
\hline Father only & $1.23(1.13$ to 1.34$)$ & $0.95(0.88$ to 1.03$)$ & $1.26(1.14$ to 1.38$)$ & $1.11(1.02$ to 1.21$)$ & $1.14(1.05$ to 1.23$)$ \\
\hline Both & $1.24(1.14$ to 1.36$)$ & $1.05(0.96$ to 1.14$)$ & $1.38(1.25$ to 1.53$)$ & $1.07(0.97$ to 1.17$)$ & $1.28(1.17$ to 1.39$)$ \\
\hline Other & $1.52(1.38$ to 1.66$)$ & $0.99(0.90$ to 1.08$)$ & $1.46(1.37$ to 1.58$)$ & $1.33(1.21$ to 1.46$)$ & $1.46(1.32$ to 1.58$)$ \\
\hline Active smoking $($ Never $=1.00)$ & 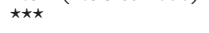 & 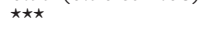 & $\star \star \star$ & 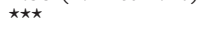 & 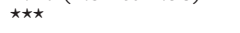 \\
\hline Ex-smoker & $1.13(1.06$ to 1.21$)$ & $1.46(1.37$ to 1.55$)$ & $1.47(1.37$ to 1.58$)$ & $1.15(1.08$ to 1.23$)$ & $1.44(1.36$ to 1.53$)$ \\
\hline$<$ Once weekly & $1.11(0.93$ to 1.31$)$ & $1.71(1.45$ to 2.03$)$ & $1.60(1.34$ to 1.92$)$ & $1.42(1.20$ to 1.67$)$ & $1.68(1.44$ to 1.96$)$ \\
\hline Weekly not daily & $1.38(1.17$ to 1.62$)$ & 1.96 (1.66 to 2.33$)$ & 2.03 (1.72 to 2.40$)$ & $1.48(1.26$ to 1.74$)$ & $1.82(1.56$ to 2.11$)$ \\
\hline Daily & $2.07(1.86$ to 2.30$)$ & 1.99 (1.78 to 2.22$)$ & $2.68(2.41$ to 2.99$)$ & $1.53(1.37$ to 1.70$)$ & $2.22(2.00$ to 2.46$)$ \\
\hline
\end{tabular}

${ }^{\star} \mathrm{p}<0.05,{ }^{\star \star} \mathrm{p}<0.01,{ }^{\star \star \star}{ }^{\star} \mathrm{p}<0.001$ for heterogeneity.

dry night cough. Some of the symptoms were associated with certain types of housing, but the relationships were not consistent.

\section{Discussion}

This survey was conducted throughout Britain in a way that ensured comparability of data and representation of all areas, and response rates were high. Although there are inevitable uncertainties about the accuracy of symptom reporting, there is no reason to suspect differential bias in comparing children in various parts of the country or with particular characteristics. This analysis examines the relationships between certain respiratory symptoms and various environmental factors, allowing the effect of each factor to be considered independently by means of logistic regression. As the study is cross sectional, the effects may be underestimated if factors had been modified because of perceived relationships with symptoms. Other aspects of the prevalence of asthma, hay fever, and eczema have been published separately. ${ }^{7}$

The prevalence of some of these symptoms was markedly higher than that reported in other surveys. For example, wheeze during the past year was reported by a third of these children, whereas surveys of 12 year old children in South Wales ${ }^{10}$ and Scotland ${ }^{11}$ found wheeze during the past year in $15 \%$ and $19 \%$, respectively. In these surveys the questionnaires were completed by the parents, whereas the present survey addressed the children directly. In a pilot study it was found that wheeze and cough were reported more frequently by children than by parents answering on their behalf, presumably because the children were aware of symptoms that occurred when they were not in their parents' company. In the present survey symptoms were reported more frequently by girls than by boys, contrary to the findings of the other surveys referred to, possibly because of the different survey methods or because the children were somewhat older. In younger children asthma and wheeze occur more frequently in boys than in girls, but the excess prevalence in boys declines with age, ${ }^{12}$ and in young adults the prevalence is higher in women than in men. ${ }^{13}$ For reasons that are unknown, the reversal of the sex ratio seems to occur during adolescence. The adjusted odds ratios show that girls are more susceptible than boys with the same degree of exposure to the environmental factors considered here.

The prevalence of wheeze was higher in Scotland than in any other region, contrary to the findings of other surveys that showed a lower prevalence in Scottish children. ${ }^{14}{ }^{15}$ Again, the results are not strictly comparable owing to differences in ages and methods. On the other hand, cough in the absence of a cold was less common in Scotland than elsewhere. The present analysis shows that these differences were not attributable to any of the environmental factors considered here.

It is at first sight surprising that the prevalence of wheeze tended to be higher in the non-metropolitan than in the metropolitan areas. For cough and phlegm the relationship was in the opposite direction. A recent report concluded that there is no convincing evidence that asthma is more common in urban areas than in rural areas in the UK, although there is limited evidence from the UK and elsewhere to suggest a modest relationship between the prevalence of asthma and local traffic density. ${ }^{16}$ A study of Swedish conscripts found a higher prevalence of asthma in Stockholm (population 670000 ) than in other areas, ${ }^{17}$ but a French survey found a lower prevalence of wheezing attacks in Marseille (population $870000)$ than in a rural area, ${ }^{18}$ while a British national survey found a similar prevalence of wheeze in urban and rural settings. ${ }^{14}$ Another 
British survey reported that children living in inner cities had more respiratory symptoms than other children, ${ }^{15}$ but this does not necessarily conflict with the present findings since most people in a metropolitan area do not live in the inner city. It seems likely that asthma and other respiratory symptoms differ in their epidemiological and aetiological associations.

Furry pets were associated with rhinitis and wheeze, occurring without rather than with colds, presumably because these animals provoke allergic reactions. Another British survey found that wheezy children were more likely than others to own a furry pet ${ }^{5}$; other surveys have failed to show this association, ${ }^{12} 1920$ possibly because parents of allergic children tend not to acquire pets. ${ }^{21}$ In so far as allergic families in this study avoided pets, the effects of pets on symptoms will have been underestimated. It is more difficult to explain the associations with phlegm and frequent colds.

Several surveys have shown an increased risk of respiratory symptoms in children whose houses contain gas cookers; a meta-analysis estimated that the odds of respiratory illness were $20 \%$ higher in these children. ${ }^{4}$ The evidence is not wholly consistent, however ${ }^{5}$; in the present survey (involving even more subjects than were available for the metaanalysis) the use of gas for cooking was associated with slightly raised odds ratios, only one of which was significantly different from unity. Larger associations occurred with heating fuels. Most symptoms were reported less frequently in houses heated only by electricity than in any other type of house, in contrast to a Canadian study that showed an association between asthma and an electric heating system..$^{22}$ Perhaps the associations with mains gas heating reflect an effect of open gas fires; the fuel used for central heating can hardly be relevant. Heating by coal, wood and oil showed little effect, except for phlegm with colds, where the association seemed to be attributable to a negative relationship with electricity rather than to a specific effect of these fuels. Other studies have reported positive, ${ }^{23}$ negative, ${ }^{24}$ and $\mathrm{no}^{25}$ associations between coal or wood fires and symptoms; in one study heating with coal or wood was apparently protective against hay fever and bronchial hyperresponsiveness. ${ }^{26}$ The effects may vary according to the type of appliance and the climate. Bottled gas and paraffin were associated with more symptoms than were any other of the specified fuels, possibly due to a greater production of pollutants; in an Italian survey respiratory symptoms were associated with the use of bottled gas for cooking and stoves fuelled other than by natural gas. ${ }^{27}$ But the strongest and most consistent associations with heating fuel in the present data concerned the "other" category. Children whose houses were heated by a fuel other than those specified (whether specified fuels were used or not) were much more likely than other children to report any of the symptoms. It is difficult to interpret this observation. We cannot be sure what these fuels were, since we did not ask the children to identify them, but it is obviously possible that they produce particularly toxic fumes. Presumably they comprise solid fuels other than coal and wood, and the fact that they were used mainly in the Scottish islands suggests that peat may be the principal fuel in this category. A survey in the Scottish Highlands found no relationship between heating fuel and wheeze, cough or hay fever, but it did not distinguish between coal, peat, and wood fires. ${ }^{28}$

The ownership of the house is a marker for socioeconomic status and possibly for the general condition of the house. There was no clear relationship with wheeze; there were several significant associations with cough and phlegm, but they were in opposite directions for different symptoms, so they are not easy to interpret.

All the respiratory symptoms were related in a dose dependent manner to active smoking which, in this age group, was presumably of fairly recent onset. Because a quarter of the children had smoked only at some previous time, the contribution of ex-smoking to the prevalence of wheeze in the population was as great as that of current daily smoking. Thus even temporary and short periods of smoking had substantial effects. Presumably some of the "ex-smokers" had smoked only a very few cigarettes (or just one); the high prevalence of symptoms in ex-smokers may in part reflect a tendency for those who were most obviously affected by smoking to abandon the experiment. Passive smoking was also associated with symptoms, as has been shown in numerous other studies. ${ }^{29}$ The strongest associations were with smoking by someone other than (or in addition to) a parent, probably an older sibling, who might share the same bedroom or be otherwise in close proximity to the child. While this association was positive in relation to rhinitis with itchy eyes at any time of year, it was negative in relation to these symptoms occurring only in spring or summer (presumably hay fever or other seasonal allergic rhinitis). These contrary associations were quite strong and are not easy to explain. To some extent an artefact of classification could operate in that children whose symptoms were provoked both by cigarette smoke throughout the year and by seasonal allergens were excluded from the "spring/summer" group, possibly depleting the numbers of children with seasonal rhinitis who were exposed to passive smoking. However, there is some evidence that this is not the whole explanation. A survey in adults suggested that seasonal rhinitis is more likely than perennial rhinitis to have an allergic basis, with different epidemiological associations; seasonal rhinitis was negatively associated with the presence of a smoker in the household but perennial rhinitis showed no association. ${ }^{30}$ Perhaps the two conditions involve distinct mechanisms and are affected by passive smoking in different ways. Cigarette smoke is likely to cause nasal and eye irritation at any time of year, but it may also suppress some component of the allergic immune response; the children of smoking mothers have been found to have a lower prevalence of hay fever ${ }^{28}$ and skin sensitivity, ${ }^{31}$ although the 
evidence is not consistent. ${ }^{32}$ The different effects of active and passive smoking in this regard call for further investigation.

Thus, this survey underlines the importance of smoking (active and passive) in causing respiratory symptoms in children. There was some effect of pet ownership and unexplained associations with region, non-metropolitan area, and unusual heating fuels which call for further investigation.

We thank the National Asthma Campaign for funding the study, and the staff and pupils at the schools for their participation.

1 Kiernan KE, Colley JRT, Douglas JWB, et al. Chronic cough in young adults in relation to smoking habits, childhood environment and chest illness. Respiration 1976;33:236-44.

2 Barker DJP, Godfrey KM, Fall C, et al. Relation of birth weight and childhood respiratory infections to adult lung function and death from chronic obstructive airways disease. BMF 1991;303:671-5.

3 Colley JRT, Reid DD. Urban and social origins of childhood bronchitis in England and Wales. BMF 1970;2:213-7.

4 Hasselblad V, Eddy DM, Kotchmar DJ. Synthesis of environmental evidence: nitrogen dioxide epidemiology environmental evidence: nitrogen dioxide epidemiolo

5 Strachan DP, Carey IM. Home environment and severe asthma in adolescence: a population based case-control asthma in adolescence: a popul
study. BMF 1995;311:1053-6.

6 Asher MI, Keil U, Anderson HR, et al. International study of asthma and allergies in childhood (ISAAC): rationale and methods. Eur Respir f 1995;8:483-9

7 Kaur B, Anderson HR, Austin J, et al. Prevalence of asthma symptoms, diagnosis, and treatment in 12-14 year old children across Great Britain (International Study of Asthma and Allergies in Childhood, ISAAC UK). BMF 1998;316: 118-24.

8 Francis B, Green M, Payne C. The GLIM system. Release 4 manual. Oxford: Clarendon Press, 1993.

9 Breslow NE, Day NE. Statistical methods in cancer research, volume 1. The analysis of case-control studies. IARC Publication 32. Lyon: International Agency for Research on Cancer, 1980 .

10 Burr ML, Butland BK, King S, et al. Changes in asthma prevalence: two surveys 15 years apart. Arch Dis Child prevalence: two

11 Austin JB, Russell G, Adam MG, et al. Prevalence of asthma and wheeze in the Highlands of Scotland. Arch Dis Child 1994;71:211-6

12 Clifford RD, Radford M, Howell JB. Prevalence of respiratory symptoms among 7 and 11 year old schoolchildren and association with asthma. Arch Dis Child 1989;64 $1118-25$

13 Anderson HR, Pottier AC, Strachan DP. Asthma from birth to age 23: incidence and relation to prior and concurrent atopic disease. Thorax 1992;47:537-42.
14 Strachan DP, Anderson HR, Limb ES, et al. A national survey of asthma prevalence, severity, and treatment in Great Britain. Arch Dis Child 1994;70:174-8.

15 Duran-Tauleria E, Rona RJ, Chinn S, et al. Influence of ethnic group on asthma treatment in children in 1990-1: national cross sectional study. BMf 1996;313:148-52.

16 Department of Health. Committee on the Medical Effects of Air Pollutants. Asthma and outdoor air pollution. London: HMSO, 1995.

17 Åberg N. Asthma and allergic rhinitis in Swedish conscripts. Clin Exp Allergy 1989;19:59-63.

18 Charpin D, Kleisbauer JP, Lanteaume A, et al. Existe-t-il un facteur urbain dans l'asthme et l'allergie? Rev Mal Resp 1988;5:109-14.

19 Hosein HR, Corey P, Robertson JMcD. The effect of domestic factors on respiratory symptoms and $\mathrm{FEV}_{1}$. Int 7 Epidemiol 1989;18:390-6.

20 Burr ML, Limb ES, Maguire MJ, et al. Infant feeding, wheezing, and allergy: a prospective study. Arch Dis Child 1993;68:724-8.

21 Brunekreef B, Groot B, Hoek G. Pets, allergy and respiratory symptoms in children. Int $\mathcal{F}$ Epidemiol 1992;21: $338-42$.

22 Infante-Rivard C. Childhood asthma and indoor environmental risk factors. Am $\mathcal{F}$ Epidemiol 1993;137:834-44

23 Honicky RE, Osborne JS, Akbom CA. Symptoms of respiratory illness in young children and the use of wood-burning stoves for indoor heating. Pediatrics $1985 ; 75$ : 587-93.

24 Volkmer RE, Ruffin RE, Wigg NR, et al. The prevalence of respiratory symptoms in South Australian preschool children. II. Factors associated with indoor air quality. $\mathcal{F}$ Paediatr Child Health 1995;31:116-20.

25 Tuthill RW. Woodstoves, formaldehyde, and respiratory disease. Am f Epidemiol 1984;120:952-5.

26 Von Mutius E, Illi S, Nicolai T, et al. Relation of indoor heating with asthma, allergic sensitisation, and bronchial responsiveness: survey of children in South Bavaria. BMF 1996;312:1448-50.

27 Viegi G, Paoletti P, Carrozzi L, et al. Effects of home environment on respiratory symptoms and lung function in a general population sample in North Italy. Eur Respir 7 1991;4:580-6.

28 Austin JB, Russell G. Wheeze, cough, atopy, and indoor environment in the Scottish Highlands. Arch Dis Child 1997;76:22-6.

29 Cook DG, Strachan DP. Parental smoking and prevalence of respiratory symptoms and asthma in school age children. Thorax 1997;52:1081-94.

30 Sibbald B, Rink E. Epidemiology of seasonal and perennial rhinitis: clinical presentation and medical history. Thorax 1991;46:895-901.

31 Burr ML, Merrett TG, Dunstan FDJ, et al. The development of allergy in high-risk children. Clin Exp Allergy 1997; 27:1247-53

32 Strachan DP, Cook DG. Parental smoking and allergic sensitisation in children. Thorax 1998;53:117-23. 


\title{
Effective immunosuppressive therapy in a patient with primary pulmonary hypertension
}

\author{
F Bellotto, P Chiavacci, F Laveder, A Angelini, G Thiene, R Marcolongo
}

\begin{abstract}
The case history is described of a young woman who presented with primary pulmonary hypertension and non-specific inflammatory signs. The patient received prolonged immunosuppressive treatment with low dose methotrexate and prednisone without any vasodilator agent. After one year the pulmonary artery pressure fell from a mean value of $47 \mathrm{~mm}$ $\mathrm{Hg}$ to $30 \mathrm{~mm} \mathrm{Hg}$ and there was a corresponding clinical response. This case suggests that, in patients with pulmonary hypertension of unknown origin, immunopathogenetic factors should be sought in order to consider the utility of immunosuppressive therapy.

(Thorax 1999;54:372-374)
\end{abstract}

Keywords: pulmonary hypertension; methotrexate; transforming growth factor $\beta$

Primary pulmonary hypertension $(\mathrm{PPH})$ is a rare disease of unknown origin that should be suspected in any young patient who presents with unexplained effort dyspnoea and electrocardiographic signs of right ventricular hypertrophy in the apparent absence of any underlying cause. ${ }^{1}$ Pulmonary hypertension clinically and histologically similar to $\mathrm{PPH}$ has been described in association with connective tissue diseases and other immunological disorders, also in the absence of any parenchymal lung involvement. ${ }^{2}$ Primary forms usually show a rapidly progressive course despite treatment, with a mean survival of 2.5 years. ${ }^{3}$

We describe a patient with PPH who, after treatment with immunosuppressive therapy, showed a clinical improvement.

School of Medicine, Italy

Correspondence to:

Dr R Marcolongo, Università degli Studi di Padova, Dipartimento di Medicina Clinica e Sperimentale, Servizio di Immunologia Clinica, Via Giustiniani 2, 35128 Padova, Italy.

Received 27 May 1997 Returned to authors 17 September 1997 Revised version received 14 October 1997 Accepted for publication 10 November 1997 antinuclear (ANA and ENA) and antiphospholipid antibodies, rheumatoid factor, ANCA and other autoantibodies, HIV and other infectious agents were always negative. The patient had never been pregnant nor used appetite suppressants or any other drug potentially able to induce pulmonary hypertension. ${ }^{1}$ There were no signs suggestive of connective tissue disease.

Laboratory tests gave the following results: erythrocyte sedimentation rate, $29 \mathrm{~mm} / \mathrm{h}$; fibrinogen, $5.32 \mathrm{~g} / 1$ (normal $2.0-4.0 \mathrm{~g} / \mathrm{l}$ ); antithrombin III $1.42 \mathrm{IU} / \mathrm{ml}$ (normal 0.8-1.2); positive indirect antiglobulin test; serum IgE, $1.817 \mathrm{kU} / 1$ (normal <200) with negative RAST; serum IgG, $19.30 \mathrm{~g} / 1$ (normal $8.0-15.0 \mathrm{~g} / \mathrm{l}$ ); serum IgA, $0.32 \mathrm{~g} / 1$ (normal $1.00-4.90 \mathrm{~g} / \mathrm{l}$ ); ferritin, $1808 \mathrm{ng} / 1$ (normal 4-233 ng/l); positivity for HLA-DR4 antigen; moderate increase in peripheral blood CD8+ lymphocytes. Other routine tests were negative or normal.

Lung scans with $99 \mathrm{~m}$-technetium labelled albumin macroaggregates and 133-xenon gas and deep vein Doppler ultrasonography of the lower extremities were normal. The electrocardiogram, which had been normal six months earlier, showed signs of right ventricular (RV) pressure overload. The chest radiograph showed normal lung fields and a marked distension of the main pulmonary artery. Echocardiography revealed moderate RV hypertrophy and dilatation, with an RV ejection fraction of $39 \%$, mild tricuspid incompetence, and an estimated pulmonary pressure of $75 \mathrm{~mm} \mathrm{Hg}$. Spirometric findings were normal: $\mathrm{FEV}_{1} 2.431$ (94\% of predicted normal) and FVC 2.601 (119\% of predicted normal), FRC 2.081 , TLC 4.161 (101\% of predicted normal). Arterial blood gas tensions on room air were $\mathrm{PaO}_{2} 94 \mathrm{~mm} \mathrm{Hg}(12.5 \mathrm{kPa}), \mathrm{SaO}_{2} 97 \%$, pH 7.41, $\mathrm{PaCO}_{2} 40 \mathrm{~mm} \mathrm{Hg}(5.3 \mathrm{kPa}) ;$ TLCO was $23.5 \mathrm{ml} \mathrm{CO} / \mathrm{min} / \mathrm{mm} \mathrm{Hg}$. Right heart catheterisation showed a pulmonary arterial pressure of 65/30 (mean 47) $\mathrm{mm} \mathrm{Hg}$, pulmonary capillary wedge pressure of $3 \mathrm{~mm} \mathrm{Hg}$, cardiac output $3.6 \mathrm{1} / \mathrm{min}$, and vascular resistance of 12.2 Wood units. Mean values of pulmonary arterial and capillary wedge pressures and vascular resistance were substantially unaffected by prolonged intravenous infusion of diltiazem (15 mg/kg/min for four hours) or supplemental oxygen. 

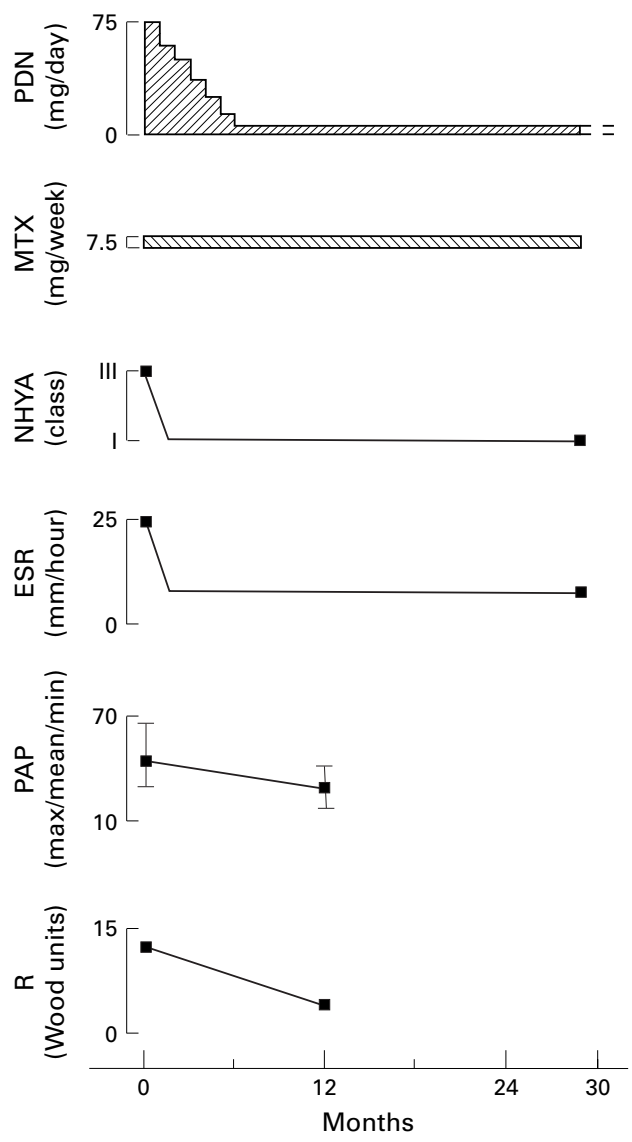

Figure 1 Relationship between the clinical course and immunosuppressive treatment. $P D N=$ prednisone; $M T X=$ methotrexate $; E S R=$ erythrocyte sedimentation rate; $P A P$ $=$ pulmonary artery pressure; $R=$ vascular resistance.

Open lung biopsy specimens showed diffuse involvement of small arteries and arterioles, intimal fibrocellular proliferation and severe luminal narrowing; there were no signs of inflammatory, thromboembolic, or pulmonary veno-occlusive disease, suggesting the diagnosis of $\mathrm{PPH} .{ }^{4}$ Immunofluorescence staining for immunoglobulins, complement, and fibrinogen was negative.

Given the rapid progression of the disease, the lack of any acute reactivity to vasodilator agents, and the suspicion of an immune mediated pathogenetic mechanism because of the persistent signs of systemic inflammation, immunosuppressive therapy with oral prednisone $(1.5 \mathrm{mg} / \mathrm{kg} /$ day for one month gradually tapering to $5 \mathrm{mg}$ /day over six months) and methotrexate $(7.5 \mathrm{mg} /$ week over 36 hours followed by low dose folinic acid, $2.5 \mathrm{mg} /$ week) was administered for one year with the patient's informed consent.

The patient received only immunosuppressive treatment without any vasodilator or anticoagulation. She became completely asymptomatic in a few weeks, the inflammatory indices steadily returning to within normal ranges. The patient's quality of life improved dramatically (NYHA class I), enabling her to perform even some sports. A right heart catheterisation control after 12 months showed a marked reduction in both pulmonary arterial pressure
(43/18 $\mathrm{mm} \mathrm{Hg}$, mean 30) and vascular resistance (4.36 Wood units) with a cardiac output of $5.5 \mathrm{l} / \mathrm{min}$. The electrocardiographic signs of RV overload were no longer present and RV function appeared normal on echocardiography.

After 30 months methotrexate has been discontinued and the patient, who is still taking prednisone, $5 \mathrm{mg} /$ day, remains well.

\section{Discussion}

In this patient immunosuppressive therapy alone produced a significant decrease in pulmonary vascular resistance, steadily reducing the right heart overload and leading to the complete remission of any sign or symptom of pulmonary hypertension. The variable clinical course of PPH and the fact that some patients will remit spontaneously without treatment have been described previously ${ }^{5}$ so we cannot theoretically exclude the possibility of a spontaneous remission that occurred coincidentally with immunosuppressive treatment. Nevertheless, there is a close temporal relationship between immunosuppression and disease remission (fig 1).

It has recently been shown that plexogenic arteriopathy may result from deregulated endothelial cell growth. ${ }^{6}$ Functionally activated immunocompetent cells surrounding the pulmonary vessels, even in small numbers, may be responsible for the production of local mediators that could favour abnormal endothelial proliferation. In fact, lymphocyte and macrophage released cytokines and growth factors, in addition to the appearance of systemic manifestations, seem also to be involved in pulmonary vascular remodelling. ${ }^{78}$ Both the release of immunologically derived factors such as interleukin 1 and transforming growth factor $\beta$, and of endothelium derived vasoconstrictive factors (thromboxane and endothelin) together with the impaired production of vasodilator molecules (prostacyclin and nitric oxide), might equally account, at least in some cases, for the pathogenesis of PPH. ${ }^{1}$ Thus, pulmonary hypertension and pulmonary vascular remodelling are linked and are mutually self-sustaining. ${ }^{8}$

In patients with NYHA class III or IV and no response to oral calcium channel blockers or a moderate to minimal fall in pulmonary vascular resistance in response to short acting vasodilators, anticoagulation and long term epoprostenol infusions are currently recommended as a possible bridge to lung transplantation. ${ }^{1}$ Although immunosuppressive agents are not usually used in these patients, their rational use may be appropriate in some instances. Indeed, by inhibiting the production of pro-inflammatory and proliferative fibrogenic cytokines, and by controlling both immunologically induced intimal hyperplasia and the general immune response, immunosuppression might theoretically arrest and even relieve vascular obstruction and systemic symptoms, interrupting the vicious circle of "cell growth-vasomotor coupling". Favourable effects have been anecdotally reported in patients with pulmonary 
hypertension associated with autoimmune disorders who have been treated with other immunosuppressive agents such as cyclophosphamide or cyclosporin A. ${ }^{210-12}$ However, the possible efficacy of methotrexate and prednisone in PPH observed in our patient needs to be confirmed.

Since a recent study reported that a subset of patients with PPH may have an immune mediated disease, ${ }^{13}$ we suggest that even minor signs of immune activation should be carefully evaluated in patients with pulmonary hypertension of unknown origin in order to assess the pathogenetic responsibility of immune factors. We suggest further study of the effect of immunosuppressive treatment in the subgroup of patients with severe and uncontrollable $\mathrm{PPH}$, candidates for lung transplantation, to test the hypothesis of a direct drug induced beneficial effect that is not coincident with spontaneous remission.

1 Rubin LJ. Primary pulmonary hypertension. $N$ Engl f Med 1997;336:111-17.

Doll NJ, Salvaggio JE. Pulmonary manifestation of collagen vascular disease. Semin Respir Med 1984;5:273-81.
3 D'Alonzo GE, Barst RJ, Ayres SM, et al. Survival in patients with primary pulmonary hypertension. Results from a national prospective registry. Ann Intern Med 1991;115: 343-9.

4 Bjornsson J, Edwards WD. Primary pulmonary hypertension: a histopathologic study of 80 cases. Mayo Clin Proc 1985;60:16-25.

5 Rozkovec A, Montanes P, Oakley CM. Factors that influence the outcome of primary pulmonary hypertension. Br Heart f 1986;55:449-58.

6 Tuder RM, Groves B, Badesch DB, et al. Exuberant endothelial cell growth and elements of inflammation are present in plexiform lesion of pulmonary hypertension. Am F Pathol 1994;144:275-85.

7 Humbert M, Monti G, Brenot F, et al. Increased interleukin-1 and interleukin-6 serum concentrations in severe primary pulmonary hypertension. Am $\mathcal{f}$ Respir Crit Care Med 1995;151:1628-31.

8 Voelkel NF, Tuder RM. Cellular and molecular mechanisms in the pathogenesis of severe pulmonary hypertension. Eur Respir ₹ 1995;8:2129-38.

9 Scott PH, Peacock AJ. Cell signalling in pulmonary vascular cells: do not shoot the messenger! Thorax 1996;51:864-6.

10 Goupille P, Fauchier L, Babuty B, et al. Precapillary pulmonary hypertension dramatically improved with high doses of corticosteroids during SLE. F Rheumatol 1994;21:1976-7.

11 Morelli S, Giordano M, De Marzio P, et al. Pulmonary arterial hypertension responsive to immunosuppressive therapy in SLE. Lupus 1993;2:367-9.

12 Dahl M, Chalmers A, Wade J, et al. Ten year survival of a patient with advanced pulmonary hypertension and MCTD treated with immunosuppressive therapy. $\mathcal{F}$ Rheumatol 1992;19:1807-9.

13 Morse JH, Barst RJ, Fotino M, et al. Primary pulmonary hypertension: immunogenetic response to high-mobility group (HMG) prot

\section{LETTERS TO THE EDITOR}

\section{Resection rates in lung cancer}

The recent article by Laroche $e t a l^{1}$ is an eloquent reminder that standardised care, hopefully based upon evidence (or at least consensus), can help to ensure that the quality of care is based less on postcode and more upon clinical need. However, the authors and the accompanying editorial ${ }^{2}$ do not emphasise the problems in comparing surgical resection rates for lung cancer with other European countries and the USA.

Much international literature in this area is not directly comparable with that in the UK for at least one reason-namely, that the denominators used may be very different. One study quoted by Laroche et al from the Netherlands described a resection rate for lung cancer of over $20 \%,{ }^{3}$ but used a denominato made up only of patients with a histological diagnosis seen at the related hospitals. The UK data commonly available comprise cases with and without histological verification, including those notified by death certification. The proportion of lung cancer notifications without histological confirmation registered at the West Midlands Cancer Intelligence Unit was over $40 \%$ in 1996. Many cases of lung cancer present in a terminal phase and, whilst it is recognised that some of these should perhaps have accessed the health care system earlier, a significant number of cases have truly malignant disease with very few symptoms right up until death.

This "denominator decrease" is also apparent in a frequently quoted paper from Belgium in which the study population was restricted to those who attended the hospital clinic. ${ }^{4}$ Examination of the paper quoted from the USA by Humphrey et ap shows that the denominator is reduced further as it excludes patients who had a histological diagnosis made at necropsy.

It is useful to refer back to a British paper published in the last decade based upon Cancer Registry data. Watkin $e t$ al ${ }^{6}$ quoted a $45 \%$ surgical intervention rate in patients with a histological diagnosis, considerably higher than elsewhere in the world. However, this represented a resection rate of $12 \%$ for all registered lung cancer patients. Data from the West Midlands Cancer Intelligence Unit show that the resection rate in 1996 was $20 \%$ for patients who had their lung cancer histologically confirmed before death yet $10.4 \%$ if all notifications were included in the denominator. Comparisons of process measures have their problems which are only made worse when the denominator is not comparable.

The results published by Laroche et al are interesting but longer term figures are needed to ensure that the described resection rates do not fall and, more importantly, that better patient outcomes are also observed, which are to be expected, if more patients are undergoing curative procedures. Whilst important points have been emphasised about access and information for the population, we must also strive towards comparing outcomes of care rather than just process detail. Furthermore, if process is to be compared, let us ensure that like is compared with like, an argument rightly used with respect to outcomes (case mix, stage etc).

Patients with lung cancer should have good quality care and good outcomes: this is rightly the message made by Laroche et al, not a dogma based upon spurious process comparisons.

ADRIAN PHILLIPS Wolverhampton Health Authority, Coniston House, Chapel Ash Wolverhampton WV3 OXE $U K$
GILL LAWRENCE West Midlands Cancer Intelligence Unit, Public Health Building, The University of Birmingham, Birmingham B15 2TT,

$U K$

1 Laroche C, Wells F, Coulden R, et al. Improving surgical resection rate in lung cancer. Thorax surgical resection

2 Fountain SW. Surgery for lung cancer. Thorax 1998;53:441.

3 Danhuis RA, Schutte PR. Resection rates and postoperative mortality in 7899 patients with lung cancer. Eur Respir f 1996;9:7-10.

4 Deneffe G, Lacquet LM, Verbeken E, et al. Surgical treatment of bronchogenic carcinoma: a
retrospective study of 720 thoracotomies. Ann retrospective study of 720 thor
Thorac Surg 1998;45:380-3.

5 Humphrey EW, Smart CR, Winchester DP, et al. National survey of the pattern of care for carcinoma of the lung. F Thorac Cardiovasc Surg 1990;100:837-43.

6 Watkin SW, Hayhurst GK, Green JA. Time trends in the outcome of lung cancer management: a study of 9090 cases diagnosed in the Mersey Region, 1974-86. Br f Cancer 1990;61:590-6.

AUTHORS' REPLY We agree with the letter by Dr Phillips and Dr Lawrence concerning the difficulty of defining the denominator for an accurate surgical resection rate. In Papworth we do know that the two stop lung cancer service has led to more than a doubling of the total number of patients undergoing surgical resections at Papworth. There was no increase in the number of patients undergoing pneumonectomy compared with lobectomy, failed thoracotomies, or increase in stage of disease. This surgical resection rate has persisted since the start of the two stop service in 1995 and has continued to increase. Interestingly, regions serviced by the surgical unit at Pap worth that do not use the two stop service have also reported an increase in the number of patients being referred for surgery in the last year. However, this increase has been associated with an increase in the failed thoracotomy rate and also with an increase in the 
number of patients undergoing pneumonectomy compared with lobectomy. We conclude that before the two stop service was established there was a significant number of patients with operable disease who were not being identified, but that multidisciplinary review of potentially operable patients is necessary to prevent inappropriate referrals for surgery.

C M LAROCHE Papworth Hospital, Papworth Everard, Cambridge CB3 8RE $U K$

\section{Surgical resection rate in lung cancer}

We read with interest the study of Laroche et $a l .{ }^{1}$ Clearly the system they describe with a multidisciplinary clinic and specialist surgical input will enhance the investigative process and so probably improve the quality of the care of patients presenting to a respiratory service with possible lung cancer. We commend the authors on this.

We do, however, have serious questions as to whether the resection rate of $25 \%$ quoted is actually a true reflection on the resection rate for the whole population of patients with lung cancer within the area. In other words, it is essential to know what the absolute denominator was.

A review of registry data in the former Yorkshire region shows that only half the patients with lung cancer present in the "classical" way to a respiratory physician with a prior diagnosis of possible lung cancer. Virtually all patients who do prove operable are found in the half who present in the classical way. If experience is similar in East Anglia, then the denominator should be doubled.

In addition, we are concerned that some patients with advanced chronic obstructive disease or metastatic lung cancer would not have been referred to the clinic by the nine screening chest physicians. Moreover, the reason that small cell lung cancers were excluded from the denominator is unclear, and again will improve the apparent resection rate. We note that a number of patients were referred direct specifically for surgery from outwith the area, so increasing the numerator.

The authors describe an innovative process for the management of the patient with presumed lung cancer. However, it would be inappropriate to regard the $25 \%$ resection rate quoted as a benchmark and a possible audit standard for other lung cancer services, particularly where comorbidity is likely to be higher than in East Anglia.

$$
\begin{array}{r}
\text { C K CONNOLLY } \\
\text { Consultant Physician, } \\
\text { Darlington, UK } \\
\text { I JOHNSTON } \\
\text { Consultant Physician, } \\
\text { Nottingham, UK } \\
\text { R MILROY } \\
\text { Consultant Physician, } \\
\text { Glasgow, UK } \\
\text { R JONES } \\
\text { Consultant Oncologist, } \\
\text { Glasgow, UK }
\end{array}
$$

1 Laroche C, Wells F, Coulden R, et al. Improving surgical resection rate in lung cancer. Thorax 1998;53:445-9.
AUTHORS' REPLY We agree with the above signatories that our surgical resection rate of $25 \%$ may not reflect the resection rate for the whole population of lung cancer patients within the area. What is certain is that our investigation process immediately led to a significant increase in the overall number of patients being referred for surgical resection from within the referral region, and that the number has continued to rise with the increased number of referrals into the system. We have found problems ourselves in attempting to obtain a true figure for overall resection rates.

Cancer registry data include patients who have not undergone histological confirmation and, as we have found from our service, many patients with presumed lung cancer have in reality alternative diagnoses. However, recognising that virtually all patients who do prove operable present in the classical way to chest physicians, it is important to note that, as mentioned in our paper, resection rates of patients with histologically confirmed lung cancer are still less than $10 \%$ in some units.

We would therefore propose that, while continually trying to increase the proportion of patients undergoing histological confirmation, the surgical resection rate of patients with confirmed non-small celllung cancer would be the most useful benchmark audit indicator for lung cancer services.

C M LAROCHE Papworth Hospital, Papworth Everard, Cambridge CB3 8RE,

\section{Repeatability of breathlessness measurements in cancer patients}

Visual analogue scales (VAS) and numerical rating scales are commonly used to assess breathlessness in patients with cancer..$^{-3}$ Their repeatability in this situation has not, however, been assessed in a way that allows calculation of the sample size required to design studies with sufficient power to detect a change in breathlessness. We asked 31 patients with breathlessness due to cancer to complete a $100 \mathrm{~mm}$ VAS and a numerical rating scale (from 0 to 10 ) on three occasions, twice on one day one hour apart and then again after a mean (range) of 2 (1-8) days. Patients were asked to rate their breathlessness "right now" and the worst and average severity of breathlessness and the degree of bother it had caused in the preceding 24 hours. Identical words were used to anchor the ends of both scales-for example, "not breathless at all" and "breathlessness as bad as you can imagine".

Sample sizes were calculated using the following equation ${ }^{4}$

Table 1 Sample size required to detect a change in breathlessness of 25\% for VAS and the numerical rating scale

\begin{tabular}{lll}
\hline & Visual analogue scale & Numerical rating scale \\
\hline Breathlessness 'right now' & $50(25 ; 13)$ & $31(3.0 ; 1.2)$ \\
Worst breathlessness over the past 24 hours & $36(51 ; 22)$ & $14(5.8 ; 1.4)$ \\
Average breathlessness over the past 24 hours & $30(33 ; 13)$ & $28(3.7 ; 1.4)$ \\
Bother over the past 24 hours & $67(36 ; 22)$ & $38(3.8 ; 1.7)$
\end{tabular}

* The mean rating of breathlessness and the standard deviation of the difference between the two tests are given in parentheses. where $\sigma=$ the standard deviation of the difference between tests, $\delta=$ a specified reduction in the mean, $\mathrm{Z}=$ the critical values from the Normal distribution to achieve the selected levels of significance and power, $\alpha=$ level of significance, and $\beta=$ the power of the test. Table 1 illustrates the sample sizes required to have a reasonable chance of detecting the effect of an intervention that reduced breathlessness scores over a few days in patients

$n=\left[\frac{\sigma}{\delta}\right]^{2}\left(\mathrm{Z}_{1-\alpha / 2}+\mathrm{Z}_{1-\beta}\right)^{2}+2 \mathrm{Z}_{1-\alpha / 2}$

with cancer by $25 \%(p=0.05$; power $=90 \%)$.

The sample size required, reflecting the repeatability, varies with the particular aspect of breathlessness being measured. The numerical rating scale was a more repeatable measure than the VAS. We conclude that many studies that have examined the effect of an intervention on breathlessness in patients with cancer have not had sufficient power to detect a $25 \%$ change following the intervention.

$$
\begin{array}{r}
\text { A WILCOCK } \\
\text { V CROSBY } \\
\text { D CLARKE } \\
\text { A TATTERSFIELD } \\
\text { Nottingham City Hospital, } \\
\text { Nottingham } \\
\text { NG5 1PB, UK }
\end{array}
$$

1 Bruera E, Macmillan K, Pither J, et al. Effects of morphine on the dyspnea of terminal cancer patients. $f$ Pain Symptom Management 1990;5:341-4

2 Corner J, Plant H, A'Hern R, et al. Nonpharmacological intervention for breathlessness in lung cancer. Palliative Med 1996;10:299-305.

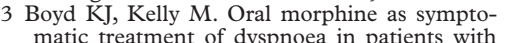
81.

4 Machin D, Campbell MJ. Statistical tables for the design of clinical trials. Oxford: Blackwell Scientific, 1987.

\section{COPD guidelines}

The BTS guidelines for the management of chronic obstructive pulmonary disease (COPD) state that use of ventilatory support or doxapram should be considered during acute exacerbations of respiratory failure in patients with arterial $\left[\mathrm{H}^{+}\right]>55 \mathrm{nmol} / \mathrm{l}(\mathrm{pH}$ $<7.26),{ }^{1}$ which implies that these measures should not be considered when $\left[\mathrm{H}^{+}\right]$is below this level. The paper cited to support this recommendation reported an uncontrolled prospective study of the application of guidelines including this criterion in COPD management, ${ }^{2}$ but the figure of $\left[\mathrm{H}^{+}\right]$ $>55 \mathrm{nmol} / \mathrm{l}$ originated from much earlier work observing that this degree of acidosis predicted increased mortality. ${ }^{3}$ The prospective study was not designed to test the hypothesis that only patients with $\left[\mathrm{H}^{+}\right]>55 \mathrm{nmol} / 1$ should receive respiratory support, and noted, firstly, that clinical judgement led to doxapram being given at lower levels of $\left[\mathrm{H}^{+}\right]$in 10 of 37 advanced cancer. Palliative Med 1997;11:277- 
episodes in which it was used and secondly that, on retrospective analysis, $\left[\mathrm{H}^{+}\right]>53 \mathrm{nmol} /$ $(\mathrm{pH}<7.28)$ was a better predictor of mortality. ${ }^{2}$ The only placebo controlled trial of doxapram for respiratory failure in COPD demonstrated improvement in blood gas parameters in patients with a mean arterial $\left[\mathrm{H}^{+}\right]$of $46 \mathrm{nmol} / \mathrm{l}(\mathrm{pH} 7.34),{ }^{4}$ and recent controlled trials of non-invasive ventilation have also shown benefit in subject groups with a mean $\left[\mathrm{H}^{+}\right]$below $55 \mathrm{nmol} / 1 .^{56}$ There is a risk that strict application of the BTS guidelines may result in treatment being delayed or withheld from patients with respiratory failure and worsening acidosis on controlled oxygen therapy whose $\left[\mathrm{H}^{+}\right]$has not risen to $55 \mathrm{nmol} / \mathrm{l}$, when there is no definitive evidence that such patients cannot benefit from doxapram or ventilatory support. Further trials are clearly needed to define more precisely which patients can benefit from these treatments, but meanwhile can I suggest that this recommendation be reconsidered?

ADAM WHITTLE

Chest Heart and Stroke Scotland Research Fellow, Respiratory Medicine Unit Western General Hospital, Edinburgh EH4 2XU, UK

1 British Thoracic Society. BTS guidelines for the management of chronic obstructive airways
disease. Thorax 1997;52 (Suppl 5):S19.

2 Jeffrey AA, Warren PM, Flenley DC. Acute hypercapnic respiratory failure in patients with chronic obstructive lung disease: risk factor and use of guidelines for management. Thorax 1992;47:34-40

3 Hutchison DCS, Flenley DC, Donald KW Controlled oxygen therapy in respiratory failure. BM7 1964;2:1159-66.

4 Moser KM, Luchsinger PC, Adamson JS, et al. Respiratory stimulation with intravenous doxapram in respiratory failure. $N$ Engl 7 Med 1973 288:427-31.

5 Bott J, Carroll MP, Conway JH, et al. Randomised controlled trial of nasal ventilation in acute ventilatory failure due to chronic obstructive airways disease. Lancet 1993;341: structive

6 Brochard L, Mancebo J, Wysocki M, et al. Noninvasive ventilation for acute exacerbations of invasive ventilation for acute exacerbations of
chronic obstructive pulmonary disease. $N$ Engl chronic obstructive pulm.

AUTHOR'S REPLY Dr Whittle's inference from the COPD guidelines was not one that we intended to imply. Lack of comment about the use of doxapram at $\mathrm{pH}$ levels greater than 7.26 reflects the paucity of data available and the lack of clinical agreement amongst those producing the guidelines. Usage varies substantially between hospitals and the relative position versus non-invasive ventilation is unclear.

There was agreement that respiratory failure should be actively managed according to the changing acid-base balance and that a $\mathrm{pH}$ of less than 7.26 should always be a cause for action. Lesser degrees of acid-base abnormality require clinical interpretation but $\mathrm{I}$ would agree that patients with COPD and respiratory failure should not be denied active management.

M G PEARSON

Aintree Hospitals NHS Trust, University Hospital Aintree, Liverpool $L 97 A L, U K$

\section{BOOK REVIEW}

Lecture Notes on Respiratory Medicine. 5th Edition. Bourke SJ. (Paperback, 205 pp. £14.95). UK: Blackwell Science, 1998. ISBN 0632049685.

In the preface to the fifth edition of this book, the author's stated aim is to provide a summary of current respiratory medicine for the medical student, junior doctors preparing for examinations, and general physicians undertaking continuing medical education.

The first chapter deals with the anatomy and physiology of the respiratory system and the second covers history taking and examination. The chapter on pulmonary function tests includes well annotated examples of spirometric tracings and flow-volume loops. The chapter on radiology includes clear diagrams and radiographs. There is a particularly helpful figure which explains the often confused anatomy of the mediastinum as seen on CT scanning.

The following chapters cover the full range of respiratory conditions. They are short but do not stint on detail. Topics covered include up to date opinion on the aetiology and pathology of asthma, advances in the understanding and treatment of cystic fibrosis, the current global epidemic of tuberculosis, current BTS guidelines on the management of asthma and COPD, and a lucid section on the respiratory manifestations of AIDS. Throughout, the text is supplemented by well laid out tables, graphs, and figures from important papers and generally well reproduced radiographs and CT scans. A feature particularly enjoyed were the numerous (and some humorous) line drawings by R A L Brewis himself, including the memorable "blue bloater and pink puffer" picture on page 117 .

In its aim to provide a text book for undergraduates, junior doctors, and general physicians this work succeeds admirably. As an aid to ward and clinic based learning it has the distinct advantage over its predecessor of fitting into the pocket of a white coat (just). Its attention to detail and clarity will make it a useful work for those undertaking postgraduate examinations and those generalists updating their knowledge of the subject.-AM

\section{NOTICES}

\section{0th British Association of Day Surgery}

The 10th annual scientific meeting and exhibition of the British Association of Day Surgery (BADS) will be held at Bournemouth International Centre, Bournemouth, UK on 3-5 June 1999. The deadline for abstracts is 31 March 1999. Enquiries regarding registration, abstracts and the exhibition should be addressed to: Kite Communications, The Silk Mill House, 196 Huddersfield Road, Meltham, West Yorkshire HD7 3AP. Tel: 01484 854575. Fax: 01484854576 e mail: info@kitecomms.co.uk. Enquiries regarding BADS membership should be addressed to: British Association of Day Surgery, 34-43 Lincoln's Inn Fields, London WC2A 3PA, UK. CME applied for.

\section{COPD: New \\ Developments and \\ Therapeutic Opportunities}

A course on "COPD: New Developments and Therapeutic Opportunities", suitable for physicians or scientists with an interest in the pharmacology and therapeutics of COPD, organised by Professor Peter Barnes will be held on 14-16 June 1999 at Imperial College School of Medicine at National Heart \& Lung Institute in collaboration with Royal Brompton Hospital, Dovehouse Street, London. For further information contact the Postgraduate Education Centre, National Heart \& Lung Institute, Dovehouse Street, London SW3 6LY, UK. Tel: 0171351 8172. Fax: 0171376 3442 .

\section{CORRECTION}

\section{Respiratory symptoms and home environment in children}

In the paper entitled "Respiratory symptoms and home environment in children: a national survey" by M L Burr et al which appeared on pages $27-32$ of the January 1999 issue of Thorax, the authors regret that three lines were transposed in table 2. The corrected section of this table relating to housing is shown below.

In addition, the address of Professor D P Strachan was omitted from the address panel on the first page of the paper. His address is: Department of Public Health Sciences, St George's Hospital Medical School, London SW17 ORE,

UK

\begin{tabular}{|c|c|c|c|c|c|c|c|c|c|c|c|}
\hline \multirow[b]{2}{*}{$\begin{array}{l}\text { Environmental } \\
\text { factor }\end{array}$} & \multirow[b]{2}{*}{ Total no. } & \multicolumn{10}{|c|}{ Percentage prevalence of symptoms in children in each environmental group } \\
\hline & & Wheeze & $\begin{array}{l}\text { Speech limiting } \\
\text { wheeze }\end{array}$ & $\begin{array}{l}\text { Wheeze } \\
\text { without colds }\end{array}$ & $\begin{array}{l}\text { Rhinitis, } \\
\text { itchy eyes }\end{array}$ & $\begin{array}{l}\text { Spring/ } \\
\text { summer rhinitis }\end{array}$ & $\begin{array}{l}\text { Cough with- } \\
\text { out colds }\end{array}$ & $\begin{array}{l}\text { Phlegm } \\
\text { with colds }\end{array}$ & $\begin{array}{l}\text { Phlegm } \\
\text { without colds }\end{array}$ & $\begin{array}{l}>3 \text { colds per } \\
\text { year }\end{array}$ & $\begin{array}{l}\text { Dry night cough } \\
\text { without colds }\end{array}$ \\
\hline \multicolumn{12}{|l|}{ Housing } \\
\hline Owned & 18338 & 33.5 & 8.3 & 21.2 & 17.9 & 6.7 & 27.2 & 62.0 & 19.7 & 26.3 & 43.7 \\
\hline Council & 5059 & 34.4 & 10.0 & 22.1 & 20.6 & 5.8 & 36.2 & 58.3 & 26.3 & 30.1 & 50.6 \\
\hline Other rented & 1013 & 34.9 & 9.7 & 21.5 & 21.4 & 7.4 & 32.7 & 63.2 & 23.2 & 27.9 & 47.0 \\
\hline Other & 983 & 36.5 & 11.0 & 22.5 & 20.3 & 5.9 & 32.8 & 58.9 & 22.2 & 30.5 & 48.8 \\
\hline
\end{tabular}

